\title{
Trans-modernism and a Legon tradition of African philosophy
}

\author{
Martin Odei Ajei \\ Senior Lecturer \\ Department of Philosophy and Classics \\ University of Ghana, Legon, Ghana \\ E-mail: majei@ug.edu.gh,odeiajei@gmail.com
}

Submitted: May 7, 2018/ Accepted: October 21, 2018 / Published: December 3, 2018

\begin{abstract}
Philosophic strands certainly underlie the characteristic claims of modernism, the creed whose foundational assumptions postmodern philosophy repudiates. This paper defends the thesis that three Ghanaian philosophers, who have been affiliated to the University of Ghana, Legon, have successfully created and defended a systematic and humanistic approach to philosophy in the African context that merits the status of a tradition of philosophy; and that these pioneers of a Legon tradition of philosophy espouse an eclectic, "trans-modernist" outlook that appropriates aspects of modernism and rejects some postmodernist features.
\end{abstract}

Keywords: Trans-modernism, Legon tradition, African Philosophy, postmodernism, modernism

\section{Introduction}

Three Ghanaian philosophers - Kwasi Wiredu, W. E. Abraham, and Kwame Gyekye - have had extensive association with the Department of Philosophy ${ }^{1}$, University of Ghana, Legon and exerted decisive influence on its philosophical orientation and the development of the current corpus of African philosophy. From their thoughts and orientation has evolved what I term a "transmodernist" philosophical praxis. I have argued elsewhere that their normative emphasis configures a coherent discourse that justifies joining them into a tradition of Ghanaian political philosophy ${ }^{2}$.

$1 \quad$ Now called Department of Philosophy and Classics. 
Ajei, M. O./ Trans-modernism and a Legon tradition of African philosophy

I limit my ambitions here to asserting their role in pioneering a nascent Legon tradition of normative philosophy.

By "trans-modernity", I allude to a conscious appropriation of foundational concepts and principles of the modernist canon for ideas and objectives that those elemental blocks of the canon can neither propose nor sustain, and to doing so without a methodic rejection of modernist thought. The Legon philosophers displayed dexterity in negotiating their conceptual responses through the modernist framework, without claiming to be philosophizing beyond it. Modernist concepts and aspirations were their vehicles, but they intentionally moved these vehicles toward destinations that could not entirely be claimed by modernist visions. Thus, they can be identified neither with modernism nor postmodernity, as they selectively appropriated and rejected features of both.

The philosophical orientation and praxis of these three thinkers, which configure the tradition of philosophy to which I allude in the first paragraph of this paper, are formed around rational humanism, a philosophical method, and three substantive themes. These themes are (1) the relevance of tradition to modernity, (2) the appropriate form of democracy as means of legitimating political power, and (3) the relative status of person and community. Despite their several differences, their convergences on method and thematic concerns justify joining them into a tradition. The three themes reflect concerns that emerge from a postcolonial condition, and the three philosophers responded to them, along with several others, as members of the first and second generations of professionally trained Africans philosophers in postcolonial Africa, such as Hountondji (1983) and Oruka (1990, 1997). It would therefore be misleading to insist that their philosophical concerns and practice place them in an exclusive category apart from those of other $20^{\text {th }}$ century African philosophers. However, the claim that the works of three Ghanaian philosophers disclose a distinctive approach to African philosophical practice can also be established.

Democratic theory, the relationship between person and state, and the evaluation of traditions of thought are recurrent 
themes in political theory. But unlike other African philosophers, the reflections on these themes by the Legon thinkers appear in two interlocking modes. The first is reactive, and responds to the pejorative characterizations of African thought and culture, mainly by Western thinkers, that stretch for hundreds of years and are discernible in the works of Hegel (1956) in the 19th century and, in more recent times, those by Horton (1971). The second is expository, and endeavors to expound their own thinking on these themes and on the philosophical fertility of African traditions of thought. In the Legon philosophers, the two modes always dovetail into each other, as their insistence on the relevance of African traditions to modernity invariably reflected in their critique of the denigration of African thought by Western thinkers and their confidence in the value of the constructive tenets of African traditions for modern life.

\section{The conundrum of the modern and postmodern: A critical perspective}

Before I begin to address my main subject, trans-modernism, it would be appropriate to make some drawn-out introductory remarks about modernity and postmodernity. Most narratives of the story of the project of modernity recognize its genesis in efforts by Enlightenment philosophers and their followers to develop objective science, moral universalism and aesthetic principles "according to their inner logic" (Habermas, 1981, p. 9). The story will argue how these aspirations and the efforts expended to achieve them bred, in the opinion of Habermas (1981), expectations that the arts and sciences would promote the control of natural forces, an understanding of the world and of the self, moral progress, the justice of institutions, and the happiness of human beings (pp. 8-9). These aspirations make evident that the intellectual framework of modernity contains at least three salient strands of philosophic thinking: metaphysics, epistemology and normative theory.

Several authors have identified a prejudicial streak at the core of the metaphysics of modernism, which projects the being of the Western human as ontologically superior to other forms of 
Ajei, M. O./ Trans-modernism and a Legon tradition of African philosophy

human existence, and as exemplifying human being-ness per se (Serequeberhan, 1998, pp. 142-143; Eze, 1998, p. 214). And cogent arguments have been advanced to indicate how these claims are not conclusions of pure abstract speculation on being, but conclusions saturated with intention to demonstrate that racial distinctions are necessary and rational, and on the basis of this to Europeanize humanity by substituting the model and standard of European personality for the fact of human being-ness. Serequeberhan (1998) portrays this as a "metaphysical pretext" (p.145) and "pervasive bias located in modernity's self-consciousness of itself” (p. 142); a bias which, no doubt, constitutes a fallacy of composition but which places the very existence of the 'other' into question, thereby depriving the largest portion of the human race the status of humanity.

The prejudicial metaphysics of modernity had its most candid expression in the philosophies of Hume, Kant and Hegel, foremost exponents of Enlightenment philosophy. Hume asserts in an infamous footnote to his essay "Of national characters," in his Essays, moral, political and literary, among others that: "I am apt to suspect the negroes, and in general all the other species of men (for there are four or five different kinds) to be naturally inferior to the whites. There never was a civilized nation of any other complexion than white, nor even any individual eminent either in action or speculation. No ingenious manufactures amongst them, no arts, no sciences. On the other hand, the most rude and barbarous of the whites, such as the ancient GERMAN the present TARTARS have still something eminent about them, in their valour, form of government, or some other particular. Such a uniform and constant difference could not happen, in so many countries and ages, if nature had not made an original distinction betwixt these breeds of men. Not to mention our colonies, there are NEGROE slaves dispersed all over EUROPE, of which none ever discovered any symptom of ingenuity" (Hume [1742/1777], 1985, p. 629). In Observations on the feeling of the beautiful and sublime, Kant outlines a taxonomy of race in which the European is atop, and has this to say of the African: "The Negroes of Africa have by nature no feeling that 
arises above the trifling. Mr. Hume challenges anyone to cite a single example in which a Negro has shown talents and asserts that among the hundreds of thousands of blacks who are transported elsewhere from their countries, although many of them have even been set free, still not a single one was ever found who presented anything great in art or science or any other praiseworthy quality, even though some continually rise aloft from the lowest rabble, and through special gifts earn respect in the world. So fundamental is the difference between these two races of man, and it appears to be as great in regard to mental capacities as in color" (Kant [(1764, 1960), pp. 110-111. For his part, Hegel's denigration of Africa proceeds from his claim that Africa is outside the framework of history, and has therefore contributed nothing to world history (Hegel, 1956, p. 99).

Irele (1983) rightly argues that sediments of their metaphysics of the person pervaded post-Enlightenment practical philosophy and stimulated the beginnings of anthropology in the 19th century, which in turn legitimated the ideology of Western colonial domination of Africa (pp. 12-14). Hume's infamous bigotry had immense philosophical consequences. It certainly influenced Kant's philosophical anthropology, which sought to prove that the African is less human than Whites (Eze, 1997, p.122). This pronouncement is rightfully interpreted as contributing to establish a threshold notion of moral personhood according to which some races are "excluded from full membership of the moral/political Community" (Mills 2005, p. 181). What this means is that Africans are disqualified from benefitting from the prescriptions of the categorical imperative ${ }^{3}$. Moellendorf (1992) observes, the justification of colonialism and slavery in terms of the European mission of civilization was the ideological raw material at hand for Hegel (p. 253). In fact, Hegel was emphatic in his endorsement of the slavery of Africans: "Negroes are enslaved by Europeans and sold to America. Bad as this may be, their lot in their own land is even worse, since there a slavery quite as absolute exists" (Hegel,

3 A foundational principle in Kant's ethics, which prescribes that all human beings be treated as ends in themselves but not as means to some other end. 
1956, p. 96).

Such ideology of the Enlightenment, grounded in the denigrated reality of non-European forms of existence, and its residues, justified the practices of the slave trade. Before the nineteenth century, justification of slavery was founded primarily on religious grounds - on rescuing Africans from their 'primitive religions' by introducing them to Christianity, the enlightened form of religious faith and practice. And as Stocking (1987), a historian of nineteenth century anthropology indicates, ideas about the 'inferiority' of non-Europeans justified European colonial adventure:

Civilizing efforts on behalf of dark-skinned savages could, over time, eliminate savagery from the world, not by destroying savage populations, but by modifying their hereditary incapacity. In the meantime - which might be shorter or longer depending on the weight one gave to present as opposed to cumulative past experience of it was both scientifically and morally respectable for civilized Europeans to take up the white man's burden. (p. 237)

Enlightenment philosophy underlies the epistemology of modernity, which is characterized by obsession with infallibility as the seal of epistemic certainty and the distinctive feature, reason. This fixation is not confined to discourses on the groundwork of justifiable truth and scientific progress. It applies also to progress in ethical capacity, social change and happiness. Undoubtedly, all these functions of reason are noticeable in the origins of Western philosophy, especially in Plato and Aristotle. Plato prescribed reason as the best ruler of the human psyche and the institutions of society, and the grounds of epistemic certainty are inherited from the status of apodicticity in Aristotelian logic ${ }^{4}$. But Aristotle did not insist on infallibility as the defining feature of certainty, as is shown by his affirmation of synthetic truths as grounds for justification. He conclusively affirms the validity of empirical knowledge in his

4 Here, apodictic refers to propositions that are demonstrably, necessarily or self-evidently the case. 
Posterior analytics ${ }^{5}$. On the other hand Modernist epistemology, beginning with Descartes' discovery of the cogito and Kant's re-affirmation of apodictic certainty, rule out the primacy of knowledge by induction and elevate with vehemence the pure activity of reason to the zenith of human capacity. With this, they enthrone reason as an unimpeachable ground of justifiable agency. These Enlightenment obsessions have framed the standard test in epistemological inquiry in Western philosophy, and today the notion of epistemic certainty as infallible and universalizable truth continues to linger in the position that theories are nothing more than organized epistemological orientations "intended to explain universal phenomena across space and time" (Miike, 2006, p. 20).

Within modernist epistemology, then, fundamental concepts of philosophy - and therefore of human thought - were set forth as specimens of culture-neutral reason. This referred merely to the reasoning of the Enlightenment and its intellectual heritage, and yet the 'inner logic' of this heritage was taken to validate these concepts. The history of Western thought, in Etherington's view (1996), has disclosed the logic that sustains this mode of reasoning to be the logic that sustains grand theories such as Liberalism, Marxism and Modernism, and their concomitant universalizing tendencies (p. 30).

For Lyotard (1984), who is credited with introducing the term "postmodernism" into philosophical literature, these features of modernist thought do evoke incredulity (p. xxiv); and to Eitiyebo (2014) they are pernicious and harmful (p. 68). Lyotard argues that history teaches decisively that knowledge and value emerge from "narratives" - interrelated and mutually fortifying discourses within the intellectual scheme of a culture - within which the validity of all claims within that culture can be found embedded (p.8). But modernity assigns privilege to its knowledge narrative

5 See Book i.13. And also in Book II.19: II.19, where he states that knowledge of principles are neither innate nor are they acquired from nothing. They must be acquired through a distinctive potentiality we have, and that this potentiality is sense perception. The chain goes like this: What is meant here is that perception leads to memory, which in turn underlies experience; and from experience we acquire the basis for Understanding

6 In Kant, as in Aristotle, the apodeictic certainty of a proposition is established when we know it to be necessarily true. 

and constructs a "metanarrative" out of its epistemic and normative claims. It is to such unjustified construction that postmodernism is obliged to remain ceaselessly skeptical or "incredulous". And such incredulity is heightened by the universalizing tendencies of modernity, which remains totalitarian by imposing conformity on other discourses; thereby oppressing, marginalizing, or silencing them. This is what makes modernity a pernicious framework of knowledge.

The assumptions and conclusions of the modernist vision of human progress mutated into systems of oppression and domination, manifest among others in the colonial dispossession of African agency and a resultant 'crisis of conscience. (Nkrumah, 1970, p. 78). Recognition by Western philosophers and scholars of the scale of destruction generated by the modernist canon in the second half of the twentieth century prompted "an inevitable moment of disenchantment; a sense of void and despair" about "the failure of the totalizing myth of the organized Eurocentric superstructure" (Monteiro-Ferreira, 2014, p. 92). This precipitated postmodernity.

I am concerned in this paper with postmodernity as a primary conceptual category, rather than its manifold expression and interpretation in cultural forms. I therefore understand it to denote an overarching intellectual approach to the production, dissemination, and evaluation of cultural goods that revolts against modernity and its assumptions. Among the principal features of this approach are a critique of hegemonic perspectives and dogmatic commitment; a critique of normative truths as universal paradigm; emphasis on intellectual and practical pluralism, and a celebration of difference; and a critique of oppressive paradigms (MonteroFerreira, 2014, pp. 101-102). What this means is that postmodernists dismiss Modernist universalism, foundationalism, and obsession with reason. In ontology, epistemology, and ethics, postmodernity upholds the validity of the particular and the provisional, as opposed to the privileged place of the general and the universal in modernist thinking (Parpart, 1995, p. 16). The postmodern thus brings awareness of the significance of difference and otherness, and value to plurality and partiality; and therewith affirms the value 
of inclusive thinking as opposed to the binary and diametrically opposed "either/or" categories of modernity (p. 17). This, in turn, highlights paradox, ambiguity, indeterminacy and contingency as reasonable attributes of postmodern thinking.

Baumann (1992) has reasoned that such characterization of postmodernity may seem to suggest comprehensive consensus on its meaning and ambit of activity. But disagreement on the exact nature of the postmodern revolt is also prevalent (p. xxiv). Questions endure about whether the shift in intellectual posture that characterizes postmodernity constitutes a change of paradigm at all, or whether it should be conceived merely as a movement, or a project, or a condition. One such recurring question is whether or not the intellectual space occupied by postmodernists can be sufficiently distinguished, as they intimately inhabit the structure that they critique. A range of skeptical responses have emerged to this question. Some, like Hassan's (1996) perceive postmodernism as evidence of a re-visioning of modernism (p. 389). The postmodern demonstrates the case that the culture of modernism "insists on old orders in clever or current guises, and, with the means of communication at hand, inhibits and restrains" (Hassan, 1996, p. 388). Hence the postmodern insistence on renouncing the modernist paradigm is an "oblique and always perilous movement, constantly risking falling back within what is being deconstructed" (Derrida, 1996, p. 345).

It is not difficult to fathom why the postmodernist revolt defies unanimous characterization. The sphere of its activity is indeterminate. It is inextricably implicated in the paradigm it contests, and yet claims to be operating "post" it. Thus, postmodernity tends to install, and then subvert, the very concepts it challenges: it shares elements of the modern and exhibit difference to it simultaneously. It simultaneously affiliates and revolts to it. Accordingly, one cannot posit an absolutely antithetical relationship between these concepts. Hence it is difficult to construe the relationship between them as one of complete historical and theoretical rupture, and find a single vision that canonizes the postmodern. In spite of these difficulties that pertain finding a unified vision of the postmodern 
Ajei, M. O./ Trans-modernism and a Legon tradition of African philosophy critique, it is generally accepted that features of this conceptual shift away from modernism are sufficiently delineated to ground it as an independent and cogent critique of modernity. I take this view in this paper.

\section{Postmodernity and postcolonial African philosophy}

The significance of postmodernist thought for African life is a theme that continues to jostle for attention in postcolonial scholarship. Particularly, the effect of postmodernist thinking on, and its utility for, humanistic studies in postcolonial Africa continues to be a matter of hot debate. Some authors emphasize the analogous concerns shared by philosophers in formerly colonized countries and postmodernists, such as elaborating manifestoes of and intellectual pluralism to establish affinity between the two intellectual practices. Spivak (1993), for instance, considers postcoloniality as deconstruction of "the heritage of imperialism" (p. 281). Eze and Ramose have echoed this position for the African context. Eze (1998) notes that postcolonial African philosophy ought to be "productively deconstructive" and "find ways to make sense, and speak of, the multiplicities and the pluralisms" of African experiences (p. 219); and Ramose (1999) cautions African philosophers to "abandon the path of mimetic philopraxis - the uncritical imitation of the life of non-Africans - and pursue the route of the authentic liberation of the continent" (p. 7). Yet, others perceive the aims of postmodernists as imaginatively different from African visions of humanistic achievement.

Appiah (1991) has offered perspectives that continue to refresh philosophical interest in this topic. In "Is the Post- in Postmodernism the Post- in Postcolonial?", Appiah explores the relations between conditions of "postcoloniality" and "postmodernism" in the context of African novels written in the 1950 s and the late sixties. He argues that novelists of the 1950s endorsed forms of realism and displayed proclivity for nationalism and traditionalism by legitimizing ethnographic inventions of uniform national histories and traditions; and that novelists of the 
late 1960s challenged these earlier narratives and instead celebrated the prevailing 'multiple existence' in African life (p. 353, p. 349). As such, these latter novelists championed postmodern techniques and could be categorized as "political postmodernism" (pp. 352353). But these postcolonial political postmodernists celebrated the virtues of a universal ethic, in contrast to Western-inspired postmodernism for which legitimate knowledge and values are necessarily decentered (p. 353).

In like manner, Serequeberhan (1998) contends that "hermeneutically elucidate[ing] that which has remained hidden" in the ethnocentric metaphysics that constitutes a bias in modernity's self-consciousness of itself imposes an indispensable post-modern task on contemporary African philosophical practice (pp. 142$143,156)$. This task of de-structuring the "meta-narrative" through which modernity constituted itself, the "negative and critical" task of peeling off layers of lies and misrepresentations about Africa that grounded colonial assumptions and policy and continues to sustain a crisis of conscience; must be undertaken in tandem with a positive task, one of highlighting the merits of Africa's intellectual legacy for human culture. Both of these negative and positive tasks of African philosophy aim at the goal of reclaiming agency for the African subject in the voicing of his or her own history and for constructing a constructive future. The features of postmodernism outlined earlier in this section justify considering the work described by Appiah and Serequeberhan as postmodern acts.

But if postmodern, they constitute as well Afrocentric ${ }^{7}$ postures that drive the conceptual responses of the postcolonial African philosopher. Tenets of postmodernist and African philosophical concerns intersect at several identifiable points. The postmodernist rejection of modernist universalization and impositions of Western cultural experience, and rejection of the modernist deprecation of other cultural perspectives, is widespread in African philosophical practice. So too is the postmodern emphasis on provincial and diverse cultural sites as locations of valid claims

7 I allude to Molefe Asante's definition of Afrocentrism as requiring "regaining our own [African] platforms, standing on our own cultural spaces, and believing that our way of viewing the universe is just as valid as any" (Asante, 1998, p. 8). 
to knowledge and values. African philosophical deconstruction of modernist assumptions in ontology, epistemology and ethics began in earnest at the beginning of the 20th century ${ }^{8}$ and continues to the present-day. Much effort has gone into elaboration of African philosophical perspectives on metaphysical and social realities, thereby stressing the postmodernist validity of diversity. Thus, African philosophy, like postmodernity, may be considered a counter hegemonic discourse in as much as it seeks to convey a mechanism for challenging the universalist pretentions of modernist theorists. So, where may the authors of the Legon tradition be located in this maze of the modern, postmodern and postcolonial?

\section{The trans-modernism character of the Legon tradition of African philosophy}

Given my perception of postmodernism as a revolt against the modernist paradigm, it is time to consider whether at all, and if so to what extent, it has exerted influence on the thinking of the pioneers of the Legon tradition of African philosophy. We have seen Appiah and Serequeberhan assert the coincidence, at several points, of postmodern and postcolonial African critiques of modernism. Undoubtedly, the Legon philosophers addressed philosophical concerns in ways that can be labeled as postmodernist. For instance, Wiredu's insistence that truth is nothing but opinion, or "a view from some point; and there are as many truths as there are points of view" (Wiredu, 1980, p. 115), certainly coincides with the postmodern rejection of epistemic foundationalism and universalism. Additionally, Wiredu (1996) admits that knowledge requires certainty, and that one can be certain of the truth or falsity of a claim; but unlike Descartes and neo-Cartesians, he insists that certainty does not imply infallibility (pp. 139-140). Likewise, Gyekye (1987) postulates paranormal cognition a possible form of knowledge (p. 202), subverting Hume's position that all objects of knowledge are subject to either "relations of ideas" (a priori) and "matters of fact" (a posteriori). As is well known, Hume's distinction and Kant's affirmation of it in distinguishing "analytic"

8 An instructive example of such is Danquah (1927). 
from "synthetic" propositions strengthened the view in Western philosophy that there are only two pathways to knowledge, accounted for by rationalism and empiricism. These challenges to modernist epistemology coincide with Abraham's extortion to Africans to believe they have good reason for confidence in their own cultural roots, and for them to reject those elements of culture and habits of thought acquired during the colonial period, but which are "unsuited to the dignity and needs of independent peoples" (Abraham, 2015, p. vi). But in spite of these resemblances to postmodernism, I believe it is less credible to identify them as postmodernists, rather than as trans-modernists.

It is now time to expand my brief definition of 'transmodernity' in the introduction. I mean by it that the authors of the Legon tradition are neither modernist in the strictest sense of the term, nor postmodernist in the strictest sense of the term either. They do not wholly castigate the modernist framework of knowledge and values. They appropriate aspects of it and rework these aspects while navigating their way across the segments of the framework that they reject in their bid to achieve their own objectives, without wholesale castigation of the framework. They are neither 'post' modern, for they make no claims to having moved past modernity, and they did not align with central concepts of postmodernity. Rather, their works display a keen teleology and method: the method of charting a path by transiting modernist assumptions and conclusions, toward deconstructive and reconstructive philosophical goals. In doing so, they test and rupture the outer limits of modernity, and in the process construct the basis of a novel category of philosophical knowledge formation - trans-modernity - configured around a philosophical approach and a handful of themes. The method is rational humanism. And from the set of themes that engaged their philosophical attention I will choose an ethical and a meta-philosophical subject: ethical humanism and the relationship between tradition and modernity, to illustrate their trans-modernist outlook. Evidently, their method and themes are drawn from the central modernist concepts of rationality, 
humanism and modernism.

The ethical reflections of the Legon philosophers proceed from belief in the primary responsibility of human beings to shape and give meaning to their lives and world. This is illustrated in their firm rejection of extra-human agency as ultimate justification for ethical principles and conduct. Abraham (2015) describes 'rational humanism' as a way of doing philosophy (pp. 6-7). In his view, reason is a defining characteristic of human being-ness as it equips human beings with sufficient resources to generate and constitute ultimate justifications for conduct (p. 7). Wiredu likewise emphatically endorses humanism as the foundation of morals (Wiredu, 1980, p. 6; 1992, pp. 193-194; 1996, pp. 65, 74-75, 193195). For him, one of the loftiest moral conducts, the "sympathetic identification of the interests of a person with those of others even at the cost of a possible abridgement of one's own interests" (1992, p. 193), should be achieved through rational deliberation. Gyekye (1997) too explicitly embraces humanism of the rational kind (pp. 259-260). For these philosophers, then, humans are the measure of all that is of human concern.

For these thinkers, an inherent feature of humans, which enables them to measure their concerns, is their rationality. The 'rational' part of their ethical humanism alludes to their application of critical reasoning to affirm humanistic beliefs. This was displayed in a number of ways. Firstly, it showed in their unwavering commitment to the value and universal character of reason. All three of them justified their humanistic beliefs by critical and substantive reasons. Secondly, they all rejected Hegel's racist ${ }^{9}$ annexation of reason exclusively to the European mind. Thus, Wiredu "rejects the possibility that some cultures may be of intrinsically greater merit than others because the people who founded them are, as human beings, somehow intrinsically better intellectually endowed than other human beings" (2004, p. 109). Further, they all placed great

\footnotetext{
9 I follow Kwame Appiah in understanding 'Racist' views to be those that seek to construct, encourage or justify social systems, institutions and practices that accord social significance to the biological divisions of the human species and endeavor to distribute economic, social and political goods and ills, benefits and burdens, unequally between the various races. See Appiah, "Racisms", pp. 5-8.
} 
emphasis on the clarity and precision of arguments as means of justifying claims. Such observation of the instrumental value of reason is certainly not anti-modernist.

Their work did not only 'transit' the modernist concept of rationality, by rejecting parochial attribution of the capacity to reason. They transited modernist aims as well. Implied in their rational humanistic deliberative method, as sufficiently stated in this section, is the belief in the ability of all cultures to reflect and philosophize on their experience. As first and second generation post colonial professional philosophers, they faced the task of responding to the denigration of African humanity perpetuated through the racist philosophical conclusions of modernist philosophers that sought to show that Euro-American paradigmatic forms of rational contemplation represent the thinking that real humans are capable of. And they resorted to reason to reject this claim of the racial nature of reason.

Their trans-modernist predilections are also visible in their deliberation on the concepts of tradition and modernity. Let us understand by 'traditional' or 'indigenous' African culture the social systems that flourished before Africa's encounter with Europe, features which are in practice and which continue to command the allegiance of a great number of Africans today. A tradition, in this sense, comprises a system for producing, organizing and consuming thought, with organizing principles that have the capacity to inspire, challenge and constrain its adherents. The question of the relevance of traditions to contemporary African life recurs so frequently in African philosophical discourses that Metz (2015) has observed that a distinct feature of this philosophy is its insistent attempt to ground theory in the normative resources of traditional African life (pp. 1-2).

The authors of the Legon tradition undoubtedly believed in the value of traditional resources for modern life. This is at variance with the insistent assault of modernist thinking on the importance of tradition exemplified, for instance in Horton's (1971) characterization of traditional African thought systems as 'closed' 
and intolerant of theoretical alternatives as opposed to 'open' Western scientific thought. In Horton's view, the 'closeness' of traditional society is embodied in the lack of theoretical alternatives, exemplified by an authoritarian imposition of unanimously received knowledge and values. Such unanimity of knowledge, he claims, is so strong that any challenge to it threatens stability and "evokes intense anxiety" in the traditional culture (pp. 154-155).

Undoubtedly, Horton's conclusions descend from the chorus of elaborate rationalization of European ethnocentrism embedded in the discussions of Hume, Kant and Hegel. The upshot of this is the disdain accorded to the modes of thought that do not accord with the assumptions of Western philosophical and scientific methods, for contemporary life. Such a degraded valuation of tradition is succinctly articulated in the Modernization School, which ruled theories of development from the end of the Second World War until the 1960s, and mutated into international economic policy as the Structural Adjustment Programmes (SAPs) and later as Poverty Reduction Strategy Papers (PRSPs) in the 1980s and 1990s. A consensus has emerged that modernization theory portrays 'Third World' countries as 'backward' in comparison to countries in North America and Western Europe, conceived as depositories of 'modern' values, and prescribes modeling these societies on the development paths of the West as remedy for their backwardness (Himmelstrand, 1994, p. 37; So, 1990, p. 36).

The core claims of modernization are theoretically sustained by the assumptions of Functionalism. So (1990, p. 18), who supplies the perspective contends, in Huntington's (1976) view, that modernization is a transformative process that renders "tradition" and "modernity" mutually exclusive (pp. 30-31). This perspective is derived from Talcott Parsons's (1952) articulation of the concept of pattern variables, to distinguish traditional societies from modern ones and justify why a society's traditional institutions and their values must be replaced in order for it to enter into modernity (p. 67). With this, modernization theory establishes a diametrical opposition between tradition and modernity, for if modernization 
represents the apogee of social progress and requires discarding all vestiges of traditional culture, then the goods of tradition are perceived as impediments to the surge toward social progress, and therefore cannot remain on the path toward modernity.

The three Legon philosophers strenuously reject such pejorative appraisals of traditional thought. They highlight the value of heritage for philosophy, and advocate a critical appropriation of African traditional thought and practices. Gyekye identifies traditional resources as essential sources of philopraxis, Gyekye (1995, pp. 15-16), and for Wiredu, "exploiting as much as is judicious the resources of our own indigenous conceptual schemes in our philosophical meditations" is essential for conceptual decolonization in African philosophy (1996, p. 136). A tradition is neither static nor incompatible with modernity for these philosophers. In Gyekye's (1997) view, a tradition is a cultural product that continues to inspire a wish for maintenance in subsequent generations because of its normative value to them (pp. 221-222). Subsequent generations may preserve, modify or discard an aspect of a tradition depending on whether they think it is good, bad, or sufficiently humane. This account implies a struggle, namely, the struggle to develop normative standards to refine cultural goods, and to determine whether they have become worthless. It is these continual assessments by contemporary custodians of culture that refine its intellectual products into a tradition. In this sense the modern is nothing but refined tradition, for modernity involves "innovation aimed at bringing about the kinds of progressive changes in the entire aspects of human culture necessary for the enhancement and fulfillment of human life" (Gyekye, 1997, p. 280). For Gyekye then, a commitment to modernity is implied in the normative assessment that determines which aspects of traditions merit maintenance. For this reason Gyekye perceives no diametrical opposition between tradition and modernity. In his thinking, the two terms represent two points on a continuum, and this makes a clear-cut dichotomy between them implausible. Thus, Gyekye foresees and expects modern African 
life to necessarily emerge from traditional cultural life.

Wiredu likewise affirms the relevance of tradition to modern life. For him too, a tradition is neither resistant to change nor opposed to modernity. He considers aspects of traditional African philosophies as "living or fit to be resurrected" for contemporary life, and he prescribes conceptual clarification and reconstruction as methods for identifying and appropriating valuable normative elements embedded in these philosophies for modern life. (Wiredu, 2004, p. 11). Similarly, the idea of grounding the African future in useful values of the past is central to Abraham's thinking. In The mind of Africa, he insists that the guiding principles for formulating solutions to problems in the African future ought to be those authenticated in cultural experience (2015, p. 31). It is for this reason that "our interest in our own cultures [ought to be] directed towards the future... [and for us Africans to] make the best of our present human resources, which are largely traditional" (Abraham, 2015, p. 36). The tenor of Abraham's utterances suggests that institutions and solutions are not "authenticated" if they are rooted in theoretical resources that ignore and perhaps even degrade African thought, in contradistinction to what modernization theory prescribes.

What the preceding paragraphs suggest is that the Legon philosophers appropriated the notions of 'tradition' and 'modernism' embedded in modernist thinking, and chartered a course of their own understanding and use of these concepts. Their account of tradition speaks to continual attempts to refine cultural goods, in order to facilitate quick identification of obsolete and perverted elements that ought to be discarded. This means that a tradition needs neither constrain its bearers from conceiving theoretical alternatives to its organizing principles, nor prevent debate of the merits of these principles. For them, a tradition not only inspires its adherents to elaborate and defend its tenets, but also equips its bearers to refine its constitutive ideas and practices through critical assessment. These perspectives constitute a compelling rejection of the conclusions of the Western project of modernism, as articulated by Robin Horton and the Modernization School. 
It is clear too that the Legon philosophers appropriated the notion of modernity and employed it in ways that can be distinguished from the modernity of Horton and Modernization theory. The Legon philosophers, like modernists, agreed that modernity implies the expectation to harness human thought to promote better understanding of the world, and the self; and for the pursuit of moral progress and human happiness, as we have seen Habermas assert in Section Two of this paper. Gyekye echoes Habermas by defining modernity as involving "innovation aimed at bringing about the kinds of progressive changes in the entire aspects of human culture necessary for the enhancement and fulfillment of human life". (Gyekye, 1997, p. 280).

In spite of such coincidence of understanding the Legon philosophers employed the notion of modernity to subvert Modernist ideals. Habermas (1981), for instance, acknowledges the modernist aspiration to apply human thought to develop objective science to promote the control of natural forces (1981, pp. 8-9). For several Enlightenment and later modernist thinkers, this aspiration meant overthrowing the religious tedium of the Dark Ages through scientific domination of nature. William Leiss (1994) quotes from the The new organon (1620) Francis Bacon's expectation that once the human race assumes the right over nature "which belongs to it by divine bequest, the exercise thereof will be guided by sound reason and true religion" (p. 189). Bacon was clearly mistaken. As Harvey (2003) observes, history has demonstrated sufficiently that the rationality of such domination "entailed the domination of human beings that could only lead, in the end, to a nightmare condition of self-domination" (p. 271).

It appears that the social machinery required to administer levelheaded control over science lacked the power of restraint, for as Horkheimer and Adorno (2002) observe, scientific power over human beings weakens with "every step human beings take away from the power of nature" (p. 30). Scientific domination over nature is matched by increased domination by some people over others. But neither reason nor religion has been capable of stemming the 
Ajei, M. O./ Trans-modernism and a Legon tradition of African philosophy tendency of science to simultaneously create and destroy, and the active threat to humanity by its applications for wanton destruction of the environment; and by stockpiling nuclear weapons through the doctrine of $\mathrm{MAD}^{10}$. The Legon philosophers adopted the notion of modernity and believed in its transformative powers. But for them, it did not imply domination of the natural and social world. Rather, much could be said for the idea of modernity involving an ethic of non-denomination of man by man, and for man's judicious usage of the resources of the natural world. The non-exploitative orientation of their philosophy, at the social level, is illustrated by their humanistic leanings, which in turn descends from their endorsement of the communitarian outlook of Akan societies.

Wiredu installed humanism as the foundation of morals (1980, p. 6; 1992, pp. 193-194; 1996, pp. 65, 74-75, 193-195) in the modern world. In stressing the importance of assigning to human beings the grounds of morals, he appeals to a maxim that constitutes a fundamental precept of traditional Akan moral thinking. This is onipa na ohia, to which he (1992, p. 194, 201) assigns two complementary meanings. According to him it means first, that, "human interest is the basis of all values"; and second, that "human fellowship is the most important of human needs". These two meanings yield the view that a human being must have ultimate value in all human considerations, and that what is morally good is what befits a human being. And for Wiredu, what befits a human being is what "brings dignity, respect, contentment, prosperity, joy, to man and his community" (1992, p. 6). In my view, a corollary of onipa na ohia as a moral first principle in Akan thought is onipa hia mmoa, or "a human being deserves help" or "ought to be helped." This latter precept follows from the stress on human sociality emanating from Wiredu's second construal of onipa na ohia, and when added, the appeal of onipa na ohia strengthens the moral prescription for a "sympathetic identification of the interests of a person with those of others even at the cost of

10 Mutual assured destruction (MAD) is a doctrine of military strategy, based on deterrence, in which a full-scale use of nuclear weapons by opposing sides that would cause the complete annihilation of both the attacker and the defender is considered sufficient deterrence from the use of it by either party. It is what sustains the proliferation of nuclear weapons 
a possible abridgement of one's own interests" (Wiredu, 1992, p. 193). In his view, such adjustment of human interests, emanating from the belief that the human being has ultimate value in all considerations, is the means to which the moral end of human wellbeing is secured in contemporary times without exploitation.

Gyekye (1997) likewise explicitly advocates for the modern world, a humanism grounded in the communitarian convictions of traditional Akan society (pp. 259-260). He considers the human being to be a being that is necessarily in need of social relations and mutual interdependence for adequate self-realization (p. 39). This in turn necessitates cooperation and sympathy for others. These views are elaborated in his communitarian theory that assigns equal moral worth of person and community, and in which he conceived common good as the social conditions that enables each individual to function satisfactorily in human society (p. 64), and support her escaping a "cramped and shackled self, responding robotically to the ways and demands of the communal structure" (pp. 55-56). Thus, Gyekye's moderate communitarian theory, which he advocates for adoption to foster social formation in contemporary Africa, seeks to promote the common good of mutual concern for one another without violating individual rights or degrading the dignity of an individual. As such, it dismisses the exploitation of man by man.

\section{Conclusion}

The foregoing validates the claim that the Legon philosophers perceived no diametrical opposition between tradition and modernity. In their thinking, the two terms represent two points on a continuum, and this renders a clear-cut dichotomy between them implausible. They do not assertively argue against the modernist framework of knowledge and values, but work through its concepts to reject some of its conclusions, such as those of modernization theory. In so doing, they theorize those concepts in ways that are consistent with post-modernist perspectives. But there is no visible inclination on their part to discard the framework of modernity as the majority of postmodernists advocate. Rather, they have worked to reform elements of modernity to serve the goal of constructing a 
Ajei, M. O./ Trans-modernism and a Legon tradition of African philosophy humanistic African philosophy that speaks to contemporary needs. Thus, their trans-modernist praxis is clearly illustrated in their philosophy of tradition and modernity. 


\section{References}

Abraham, W. E. (2015). The mind of Africa. Accra: Sub-Saharan Publishers. Appiah, K. A. (1990). Racisms. In D. Goldberg (Ed.), Anatomy of racism (pp. 3-17). Minneapolis: University of Minnesota Press.

Appiah, K. A. (1991). Is the post- in postmodernism the post- in postcolonial? Critical Inquiry, 17(2), 336-357.

Asante, M. K. (1998). The Afrocentric idea. Philadelphia: Temple University Press.

Baumann, Z. (1992). Intimations of postmodernity. London: Routledge.

Danquah, J. B. (1927). The moral end as moral excellence (PhD Thesis). University of London. UK.

Derrida, J. (1996). The end of the book and the beginning of writing. In L. Cahoone (Ed.), From modernism to postmodernism: an anthology (pp. 336-359). Malden: Blackwell.

Eitiyebo, E. (2014). Post-modern thinking and African philosophy. Filosofia Theoretica: Journal of African Philosophy, Culture and Religions, $3(1), 67-82$.

Etherington, N. (1996). Postmodernism and South African history. New Contree, 40(10), 28-41.

Eze, E. C. (1997). The color of reason: The idea of 'Race' in Kant's anthropology. In E. C. Eze (Ed.), Postcolonial African philosophy: A critical reader (pp. 103-140). Malden: Blackwell Publishers Inc.

Eze, E. C. (1998). Modern Western philosophy and African colonialism in African philosophy. In E. C. Eze (Ed.), An anthology (pp. 213-221). Malden: Blackwell Publishers Inc.

Gyekye, K. (1987). An essay on African philosophical thought - The Akan conceptual scheme. Cambridge: Cambridge University Press.

Gyekye, K. (1997).Tradition and modernity: Philosophical reflections on the African experience. Oxford: Oxford University Press.

Habermas, J. (1981). Modernity versus postmodernity. New German Critique, 22 (Special Issue on Modernism), 3-14.

Harvey, D. (2003). Modernity and modernism. In T. Middleton (Ed.), Modernism: Critical concepts in literary and cultural Studies Vol. 4 (1985-1991) (pp. 268-293). London: Routledge.

Hassan, I. (1996). Postmodernism: A paracritical bibliography. In L. E. Cahoone (Ed.), From modernism to postmodernism: An anthology (pp. 382-400). London: Blackwell Publishers.

Hegel, G. W. F. (1956). Philosophy of history (M. A. Sibre, Trans.). New York: Dover Publications.

Himmelstrand, U. (1994). Perspectives, controversies and dilemmas in the study of African development. In U. Himmelstrand, K. Kinyanjui \& E.

Mburugu (Eds.), African perspectives on development (pp. 16-35). London: James Currey Ltd. 
Ajei, M. O./ Trans-modernism and a Legon tradition of African philosophy

Horkheimer, M., \& Adorno, T. W. (1947/2002). Dialectic of enlightenment (E. Jephcott, Trans.). Stanford: Stanford University Press.

Horton, R. (1971). African traditional thought and Western science. In B. Wilson (Ed.), Rationality (pp. 131-171). New York: Harper Touchbooks.

Hountondji, P. H. (1983). African Philosophy: Myth and Reality. Bloomington: Indiana University Press.

Hume, D. [1742/1777] (1985). Essays, moral, political and literary. Indianapolis: Liberty Fund Inc.

Huntington, S. (1976). The change to change: Modernization, development and politics. In C. E. Black (Ed.), Comparative modernization: A reader (pp. 26-53). New York: Free Press.

Irele, A. (1993). Introduction. In P. J. Hountondji, African philosophy: Myth and reality (pp. 7-30). London: Hutchison \& Co.

Kant, I. [1764] (1960). Observations on the feelings of the beautiful and the sublime (J. T. Goldthwaite, Trans.). Berkeley: University of California Press.

Leiss, W. (1994). The domination of nature. Montreal: McGill University Press. Lyotard, J. F. (1984). The postmodern condition: A report on knowledge (G.

Bennignton \& B. Massumi, Trans.). Minneapolis: University of Minnesota Press.

Metz, T. (2005). African political philosophy. In H. LaFollette (Ed.), The international encyclopedia of ethics. Retrieved from DOI: 10.1002/9781444367072.wbiee804.

Miike, Y. (2006). Western theory in Western research? An Asiacentric agenda for Asian communication studies. The review of communication, 6 $(1,2), 4-31$.

Mills, C. (2005). Kant's Untermenschen. In A. Valls (Ed.), Race and racism in modern philosophy (pp. 169-193). Ithaca: Cornell University Press.

Moellendorf, D. (1992). Racism and rationality in Hegel's philosophy of subjective spirit. History of political thought, 13 (2), 243-255.

Monteiro-Ferreira, A. (2014). The demise of the inhuman: Afrocentricity, modernism, and Postmodernism. Albany: State University of New York Press.

Nkrumah, K. (1970). Consciencism. New York: Monthly Press.

Oruka, O. H. (1990). Ethics. Nairobi: Nairobi University Press.

Oruka, O. H. (1997). Practical philosophy. Nairobi: East African Educational Publishers.

Parpart, J. L. (1995). Is Africa a postmodern invention? Issue: A Journal of Opinion, African Studies, 23 (1), 16-18.

Parsons, T. (1952). The social system. London: Tavistock

Ramose, M. B. (2002). African philosophy through Ubuntu. Harare: Mond Books. 
Ajei, M. O./ Legon Journal of the Humanities 29.2 (2018)

Serequeberhan, T. (1997). Philosophy and post-colonial Africa. In E. C. Eze (Ed.), African philosophy: A critical reader (pp. 9-22). Malden: Blackwell Publishers Inc.

So, A. Y. (1990). Social change and development. Newbury Park: Sage Publications.

Spivak, G. C. (1993). Outside in the teaching machine. London: Routledge. Stocking, G. W. (1987). Victorian anthropology. New York: The Free Press.

Wiredu, K. (1980). Philosophy and an African culture. Cambridge, UK: Cambridge University Press.

Wiredu, K. (1992). Moral foundations of an African culture. In K. Wiredu \& K. Gyekye (Eds.), Person and community, Ghanaian philosophical studies (pp. 193-206). Washington, D. C.: Council for Research into Values and Philosophy.

Wiredu, K. (1996). Cultural universals and particulars: An African perspective. Bloomington: Indiana University Press.

Wiredu, K. (Ed.) (2004). A companion to African philosophy. Malden: Blackwell. 